\title{
Research on mechanism and performance of Lucobit modifier
}

\author{
Yemao Zhang ${ }^{1,3, a}$, Mulian Zheng ${ }^{2, b}$, Kun Wang ${ }^{3, c}$ \\ ${ }^{1}$ Key Laboratory for Special Area Highway Engineering of Ministry of Education,Chang'an \\ University, Xi'an Shan Xi 710064,China \\ ${ }^{2}$ Key Laboratory for Special Area Highway Engineering of Ministry of Education,Chang'an \\ University, Xi'an Shan Xi 710064,China \\ ${ }^{3}$ Jiang Su Provincial Communication Planning and Design Institute CO.LTD,9 Ziyun Street,Nanjing, \\ 210014 P.R. China \\ azhangyemao158@163.com, ${ }^{\mathrm{b}}$ zhengmulian@163.com, ${ }^{\mathrm{c}}$ wangkun1024@163.com
}

Keywords: Lucobit modifier; Pavement performance; Rutting resistance mechanism

Abstract. To research the performance of asphalt mixture with lucobit. Firstly, research the rutting resistance mechanism of Lucobit,through the results of influence rule of aggregate and asphalt for modifier and the modification mechanism of modifier show that Lucobit modifier improves the pavement performance of asphalt mixture by the double effect on asphalt and aggregate.And the gradation of $\mathrm{AC}-13 \mathrm{C}$ is selected to research pavement performance in this text to research the gradation applicability of Lucobit modifier and make it adapt to China's basic national conditions well. Lucobit modifier can greatly improve the high temperature performance of AC-13C asphalt mixture according to the test results.Also Lucobit is proved to have good anti-rutting performance by tracking observation of the domestic first test road with Lucobit more than three years.

\section{Introduction}

The Lucobit modified agent is developed and applied for patent by German Basifu chemical industry group in 1966[1,2]. The company of Lucobit has exclusive rights to produce a kind of polymer which is made up of the mixture of high quality polyethylene copolymer and a special kind of asphalt (ECB) [3]. A lot of research shows that Lucobit has excellent anti-rutting performance which is long-term and efficiency[4]. In the text AC-13C is chosen to research the pavement performance. Also Lucobit has good resistance to rutting by the tracking observation of the test road used Lucobit called Lidai road line which was used more than three years without significant rutting.

\section{Modified mechanism of Lucobit}

A grade 70\# asphalt was tested on the high temperature performance. Test results of DSR are shown in Table1.

\begin{tabular}{|c|c|c|c|}
\hline \multicolumn{2}{|c|}{ Temperature $\left({ }^{\circ} \mathrm{C}\right)$} & 64 & 70 \\
\hline \multirow{3}{*}{ Asphalt of A grade 70\# } & $\mathrm{G}^{* /} \mathrm{KPa}$ & 1.742 & 0.985 \\
\cline { 2 - 4 } & $\delta\left(^{\circ}\right)$ & 87.01 & 87.27 \\
\cline { 2 - 4 } & $\mathrm{G}^{*} / \sin \delta$ & 1.744 & 0.986 \\
\hline
\end{tabular}

Table 1 DSR Test results of A grade 70\# asphalt

Lucobit modified asphalt was tested on the high temperature performance. Test results of DSR 
are shown in Table2.

\begin{tabular}{|c|c|c|c|}
\hline \multicolumn{2}{|c|}{ Temperature $\left({ }^{\circ} \mathrm{C}\right)$} & 76 & 82 \\
\hline \multirow{3}{*}{ Asphalt of Lucobit modified } & $\mathrm{G}^{*}(\mathrm{KPa})$ & 1.122 & 0.864 \\
\cline { 2 - 4 } & $\delta\left(^{\circ}\right)$ & 86.27 & 86.97 \\
\cline { 2 - 4 } & $\mathrm{G}^{*} / \sin \delta$ & 1.124 & 0.865 \\
\hline
\end{tabular}

Table 2 DSR test results of Lucobit modified asphalt

Table1 and Table 2 show that $\mathrm{G}^{*} / \sin \delta$ improves two levels when asphalt of A grade $70 \#$ is added to Lucobit. It indicates that Lucobit modification plays a positive role in improving the high temperature rutting resistance of asphalt mixture.

The modification of asphalt is a physical blending process[5, 6]. The sufficient mixing of modifier and asphalt is a basic prerequisite to improve the performance of asphalt. On this basis, the light component of asphalt is adsorbed by modifier and swells. The swelling of the modifier and the rest components of asphalt interact and form a new structure system. So the performance of the asphalt obtains improvement. In the process of grinding and the stabilizer or the action of catalyst, Chain scission and crosslinking reaction happens. Then some mesh structure forms. So the viscosity and storage stability of modified asphalt is improved [7].

$80 \%$ components of Lucobit are 2 - butyl acrylate and vinyl polymer. Lucobit sets the advantages of both. Not only has excellent chemical stability, but also mechanical properties, tensile strength, weathering-resistant property, creep resistance and impact resistance has greatly improved.

\section{Analysis of pavement performance of AC-13C asphalt mixture with Lucobit}

To research the grading applicability of Lucobit modifier and make it adapt to the basic national conditions well, the gradation of AC-13C was chosen to research mix design and pavement performance in this text.

Tests were carried out over using the materials from the scene. The mix design results of AC-13C asphalt mixture are shown in Table 3.

\begin{tabular}{|c|c|c|c|c|c|}
\hline $\begin{array}{c}\text { Mixture } \\
\text { type }\end{array}$ & $\begin{array}{c}\text { Asphalt-aggregate } \\
\text { ratio }(\%)\end{array}$ & $\begin{array}{c}\text { Bulk volume } \\
\text { relative } \\
\text { density }\end{array}$ & $\begin{array}{c}\text { VV } \\
(\%)\end{array}$ & $\begin{array}{c}\text { Theoretical relative } \\
\text { density of testing }\end{array}$ & $\begin{array}{c}\text { Effective thickness } \\
\text { of asphalt film }(\mu \mathrm{m})\end{array}$ \\
\hline AC-13C & 5.1 & 2.537 & 4.5 & 2.657 & 6.7 \\
\hline
\end{tabular}

Table 3 Optimal asphalt-aggregate ratio, density and VV

Results show that the asphalt-aggregate ratio of $\mathrm{AC}-13 \mathrm{C}$ asphalt mixture is $5.1 \%$ and the $\mathrm{VV}$ is 4.5\%.The VV can meet the requirement of dense gradation asphalt mixture.

Test results of AC-13C asphalt mixture with Lucobit(7\%) and without lucobit are shown in Table 4 to Table 7.

\begin{tabular}{|r|c|c|c|c|}
\hline Mixture type & Stability(kN) & $\begin{array}{c}\text { Immersion } \\
\text { Marshall } \\
\text { stability(kN) }\end{array}$ & $\begin{array}{c}\text { Residual } \\
\text { stability } \mathrm{S}_{0} \\
(\%)\end{array}$ & $\begin{array}{c}\text { Requirement } \\
(\%)\end{array}$ \\
\hline AC-13C & 9.56 & 7.76 & 81.2 & $\geq 80$ \\
\hline $\begin{array}{r}\text { AC-13C } \\
\text { with Lucobit }\end{array}$ & 11.40 & 9.92 & 87.0 & $\geq 85$ \\
\hline
\end{tabular}

Table 4 Test results of Marshall Immersion 


\begin{tabular}{|r|c|c|c|c|}
\hline Mixture type & $\begin{array}{c}\text { Unconditional splitting } \\
\text { strength(MPa) }\end{array}$ & $\begin{array}{c}\text { Condition of splitting } \\
\text { strength } \\
(\mathrm{MPa})\end{array}$ & $\begin{array}{c}\text { TSR } \\
(\%)\end{array}$ & $\begin{array}{c}\text { Requirement } \\
(\%)\end{array}$ \\
\hline AC-13C & 0.716 & 0.556 & 77.7 & $\geq 75$ \\
\hline $\begin{array}{c}\text { AC-13C with } \\
\text { Lucobit }\end{array}$ & 0.950 & 0.794 & 83.6 & $\geq 80$ \\
\hline
\end{tabular}

Table 5 Test results of freeze-thaw splitting

\begin{tabular}{|c|c|c|c|c|c|c|c|}
\hline Mixture type & \multirow{2}{*}{$\begin{array}{c}\text { Equivalent } \\
\text { asphalt content } \\
(\%)\end{array}$} & \multicolumn{2}{|c|}{ Dynamic stability(times/mm) } & Requirement & $\begin{array}{c}\text { Coefficient of } \\
\text { variation(\%) }\end{array}$ \\
\cline { 3 - 7 } & 5.1 & 1886 & 1914 & 1774 & 1858 & $\geq 1000$ & 4.0 \\
\hline AC-13C & 5.1 & 7546 & 7125 & 7598 & 7423 & $\geq 2800$ & 3.5 \\
\hline $\begin{array}{c}\text { AC-13C with } \\
\text { Lucobit }\end{array}$ & & &
\end{tabular}

Table 6 Test results of dynamic stability

\begin{tabular}{|c|c|c|c|c|c|c|}
\hline $\begin{array}{c}\text { Mixture } \\
\text { type }\end{array}$ & $\begin{array}{c}\text { Largest } \\
\text { load } \\
/ \mathrm{kN}\end{array}$ & $\begin{array}{c}\text { Middle span } \\
\text { deflection } \\
/ \mathrm{mm}\end{array}$ & $\begin{array}{c}\text { Bending } \\
\text { tensile } \\
\text { strength/MPa }\end{array}$ & $\begin{array}{c}\text { Stiffness } \\
\text { modulus/MPa }\end{array}$ & $\begin{array}{c}\text { Failure } \\
\text { strain/ } \mu \varepsilon\end{array}$ & $\begin{array}{c}\text { Requirement } \\
/ \mu \varepsilon\end{array}$ \\
\hline AC-13C & 0.87 & 0.41 & 7.10 & 3299 & 2152 & $\geq 2000$ \\
\hline $\begin{array}{c}\text { AC-13C } \\
\text { with } \\
\text { Lucobit }\end{array}$ & 0.98 & 0.52 & 8.00 & 2937 & 2724 & $\geq 2500$ \\
\hline
\end{tabular}

Table 7 Test results of $-10^{\circ} \mathrm{C}$ trabecular bending

The results show that water stability, high temperature and low temperature performance of AC-13C asphalt mixture with Lucobit are meet the requirements.Also the results show that Lucobit can greatly improve the high temperature performance of AC-13C asphalt mixture and slightly improve other performances.

\section{Performance verification of asphalt pavement test road with Lucobit}

Lidai road line is a main road of liyang in Jiang Su province. Because of the overload vehicles passed this road frequently. Lidai road line was damaged badly before 2010.And Lidai road line was used the test road to verify the performance of Lucobit.

In November 2010 May 2011 and August 2011 respectively used the lucobit scheme to solve the problem of rutting in Lidai road line. The situation of the test road was shown in Table 8 .

\begin{tabular}{|c|c|c|c|}
\hline Name & The first paragraph & The second paragraph & The third paragraph \\
\hline Paving time & In November 2010 , & In May 2011 & In August 2011 \\
\hline length (m) & 200 & 300 & 2000 \\
\hline \multirow{2}{*}{$\begin{array}{l}\text { Pavement } \\
\text { structure }\end{array}$} & $\begin{array}{l}\text { The above layer: } \\
\text { 4cmSMA-10 } \\
\text { (70\#+9\% Lucobit) }\end{array}$ & $\begin{array}{l}\text { The above layer: } \\
\text { 4cmSMA-13 } \\
\text { (70\#+9\% Lucobit) }\end{array}$ & $\begin{array}{l}\text { The above layer: } \\
\text { 4cmSMA-13 } \\
(70 \#+9 \% \text { Lucobit) }\end{array}$ \\
\hline & $\begin{array}{l}\text { The following layer: } \\
66 \mathrm{cmAC}-13 \\
(70 \#+8 \% \text { Lucobit })\end{array}$ & $\begin{array}{l}\text { The following layer: } \\
6 \mathrm{cmAC}-13 \mathrm{C} \\
(70 \#+9 \% \text { Lucobit })\end{array}$ & $\begin{array}{l}\text { The following layer: } \\
6 \mathrm{cmAC}-13 \mathrm{C} \\
(70 \#+8 \% \text { Lucobit })\end{array}$ \\
\hline
\end{tabular}

Table 8 The situation of the test road used Lucobit in Lidai road line. 
The observation was carried on the test road in Lidai road line in 2012 and 2013. The results show that the test road with Lucobit was used in good condition. Also Lucobit was proved to have good anti-rutting performance by tracking the test road with Lucobit more than three years.

\section{Conclusions}

(1) Lucobit modifier improves the pavement performance of asphalt mixture by the double effect on asphalt and aggregate.

(2) Lucobit modifier can greatly improve the high temperature performance of AC-13C asphalt mixture and slightly improve other performances.

(3) Lucobit was proved to have good anti-rutting performance by tracking the test road with Lucobit more than three years.

\section{References}

[1]Liu L, Chen J M etc. Experiment study on the pavement performance of asphalt mixture with Lucobit 1210A [J] Journal of China \& Foreign Highway.2012(32)290.

[2]Chen J M. Lucobit Used in Rut Disease Treatment of Asphalt Mixture [J] Value Engineering. 2014.

[3]Kong Z G. A New type of modified asphalt additives Lucobit 1210A [J] Traffic World.2008.104.

[4] Khaki A M, Baladehi S H S, Akbari T, et al. The Investigation of the Impact of Lucobit Polymer on Bitumen Performance[J]. Article Author (s) page, 2013: 570.

[5]Zhou Y. Study on pavement performance of SAMPAVE crack structure layer material [D] Xi' an Chang'an University, 2007.

[6]Zhou Y, Chen S, Chen H, Zhang K. Design method of SAMPAVE asphalt mixture. Beijing: The 10th International Conference of Chinese Transportation Professionals, 2010. p. 3890

[7]TAN Y, SHI K, etc. Research on the Impact of Asphalt Character on Stress Absorbing Layer Performance [J] Journal of Highway and Transportation Research and Development 2009:2-4. 